\title{
STUDIES ON LOPHOCOLEACEAE XXII. NEW TAXA AND COMBINATIONS IN NEW ZEALAND HETEROSCYPHUS SCHIFFN.
}

\author{
JOHN J. ENGEL
}

\begin{abstract}
Heteroscyphus dentammophilus J. J. Engel \& Merrill, Heteroscyphus parallelifolius J. J. Engel, and Heteroscyphus stoloniferus J. J. Engel are new species, and Lophocolea helmsiana var. subparallela E. A. Hodgs. is a new synonym of H. parallelifolius. Heteroscyphus circumdentatus var. clasmatocoleoides J. J. Engel \& Merrill is a new variety, and Heteroscyphus menziesii (Mitt.) J. J. Engel is a new combination. All taxa are from New Zealand.
\end{abstract}

Key words: Hepaticae, Heteroscyphus, New Zealand

John J. Engel, Department of Botany, Field Museum, Chicago, Illinois 60605-2496, U.S.A.

\section{INTRODUCTION}

During preparation of the second volume of the liverwort flora of New Zealand, several interesting new taxa of Heteroscyphus have surfaced, and a nomenclatural realignment became necessary. The names are being published separately to make them immediately available for use.

This paper is dedicated to Tamás Pócs. His many insightful publications on hepatics, particularly of tropical representatives, are crucial to our understanding of plants not only from these areas, but of liverworts world wide. For example, Tamás Pócs' publications on Lejeuneaceae are critical to our understanding of representatives of that family world wide, and I have found this to be so in my studies of south temperate hepatics.

\section{TAXONOMY}

1. A new variety of Heteroscyphus circumdentatus (W. Martin \& E. A. Hodgs.) J. J. Engel \& R. M. Schust.

The name Chiloscyphus circumdentatus W. Martin \& E. A. Hodgs. was described in Martin (1950) and transferred to Heteroscyphus by Engel and Schuster (1985). Heteroscyphus circumdentatus, however, may be subdivided into two varieties as follows:
1. Leaf apex and margins subentire to entire; shoots terete, the leaves tightly imbricate and appearing distinctly concave ....... var. clasmatocoleoides

1. Leaf apices armed with 2-3 divergent, setaceous to subcaudate spines, the margins variously toothed; shoots bilaterally compressed, the leaves strongly dorsally assurgent (less often spreading), the leaves merely undulate (in dorsal view) ............ ................... var. circumdentatus

Heteroscyphus circumdentatus var. clasmatocoleoides J. J. Engel \& Merrill, var. nov.

Heteroscypho circumdentato (E. A. Hodgs.) J. J. Engel \& R. M. Schust. var. circumdentato similis, sed apice folii marginibusque subintegrae vel integrae, foliis arcte imbricatis atque in aspectu distincte concavis, caulibus teretibus differt.

Holotype: NEW ZEALAND. STEWART Is.: W end of Tin Range, near crest, N of Port Pegasus, 1200-1500 ft., Schuster 53143 (F); ISOTYPE: (CHR).

COMMENTS. When optimally developed, this species is distinctive on account of the stiffly divergent bristle-like spines at the leaf apex. However, the armature is markedly variable, and forms with subentire leaves are often seen, here distinguished as var. clasmatocoleoides. These are similar in habit, in leaf shape, and broad laminar dorsal connation to H. conjugatus (Mitt.) J. J. Engel \& R. M. 
Schust. of Tasmania, but in all such populations seen they differ by their smaller size $(2.5 \mathrm{~mm}$ wide vs. up to $6 \mathrm{~mm}$ wide in $H$. conjugatus), and in the distinctly pitted (porose) leaf cells. The cells of the uniseriate row of the teeth in $H$. conjugatus (Engel \& Schuster 1985, fig. 3: 2) lack the strongly thickened walls and communicating pits between the cells which are characteristic of the Stewart Is. plants. In addition, $H$. circumdentatus lacks the semicircular reflexed sinus at the junction of leaf and underleaf, and the coarse teeth adjacent to the sinus at the underleaf base (see Engel \& Schuster 1985, figs 3: 3; and 4: 4).

DistRIBUTION AND ECOLOGY: Endemic to New Zealand. The type is from an open scrub in the Olearia-Leptospermum zone.

\section{Heteroscyphus dentammophilus J. J. Engel \& Merrill, sp. nov.}

Heteroscypho billardierei (Schwaegr.) Schiffn. similis, sed foliis late ovatis vel deltoideis vel ovato-orbicularibus, apice foliaris in eodem plano ac laminae infernae; dentibus apicalibus quoad staturam subaequalibus vel ventralibus modice grandioribus, dentibus apicem caulinam versus non arcuatis; margine dorsali atque parte distali marginis ventralis dentata vel spinoso-dentata; plantis mediocribus, usque ad $3.5 \mathrm{~mm}$ latis differt.

Holotype: NEW ZEALAND, SouTH Is., Canterbury Prov., Mt. Cook Natl. Park, Stocking Stream, SW facing cliffs above Hooker Valley, 1280-1330 m, Engel 18261 (F); ISOTYPE: (CHR).

Plants markedly soft and spongy, turgid in appearance, flexuous, creeping to ascending to erect (especially with crowding), light olive green to yellow-brown, nitid both when fresh and dry, the shoots medium, to $3.5 \mathrm{~mm}$ wide. Branching infrequent, the branches predominantly of Frullaniatype; lateral-intercalary branches also present, from axil of leaf-underleaf connation. Stems markedly narrow for plant size, the cortical cells weakly differentiated dorsally, in a single row of slightly smaller cells, thin-walled but firm, the cortical cells ventrally in 1-2 layers of somewhat smaller cells; medullary cells larger, thin-walled. Rhizoids not seen. Leaves \pm opposite, strongly dorsally assurgent lending the shoot a subterete appearance, the leaf apices inflexed and touching or nearly so, the leaves appearing undulate in dorsal view, the leaves sometimes laxly spreading, the dorsal margin oriented at right angles to the shoot or nearly so, the leaves densely imbricate, the insertion extending to stem midline dorsally and narrowly united at the extreme base, forming a distinct ' $\mathrm{V}$ ', the orientation and insertion strongly succubous to almost longitudinal; leaves not channelled dorsally, broadly convex in dorsal half, broadly concave ventrally, \pm symmetrically broadly ovate to ovate-orbicular; apex broadly rounded, with 2 spinose teeth, the teeth often inflexed, often subsymmetrical in size or the dorsal tooth at times smaller and displaced on distal sector of dorsal margin, the teeth terminating in a uniseriate row of 2-4(5) slightly elongated cells; dorsal margin broadly arched, dentate to spinose-dentate, the teeth several, small, fewcelled, slender and with a uniseriate row of several cells to broad-based and acute, the margin distinctly decurrent at the base; ventral margin broadly arched, \pm plane, contracted near the attachment with underleaf, with several teeth similar to those of the dorsal margin, the teeth subciliiform on the ampliate portion just above the entire-margined, contracted base. Cells of median portion of leaf subisodimetric to short elongate-hexagonal, the walls unilaterally thickened, appearing \pm uniformly thick-walled in dorsal surface view, in optical section appearing thin-walled, with trigones medium and straight sided to bulging; median leaf cells 28-36 $\mu \mathrm{m}$ wide $\times 33-44 \mu \mathrm{m}$ long, not or only slightly larger near the base; marginal cells not differentiated and forming a border; surface smooth. Oil-bodies occupying fraction of cell lumen, pale olive green to pale smokey grey, (3)4-5 per cell, papillose to botryoidal, wide ovoid to less often

Fig. 1. Heteroscyphus dentammophilus J. J. Engel \& Merrill. 1 - Two gyres of main shoot, ventral view. 2 - Portion of shoot, dorsal view. 3 - Portion of shoot, lateral view. 4 - Leaf and attached underleaf. 5-8 - Leaves (all drawn to same scale). 9 Leaf apex. 10 - Median leaf cells. 11-16 - Teeth of dorsal margin of leaf (all drawn to same scale). 17 \& 18 - Underleaves (all drawn to same scale). (All from type). 


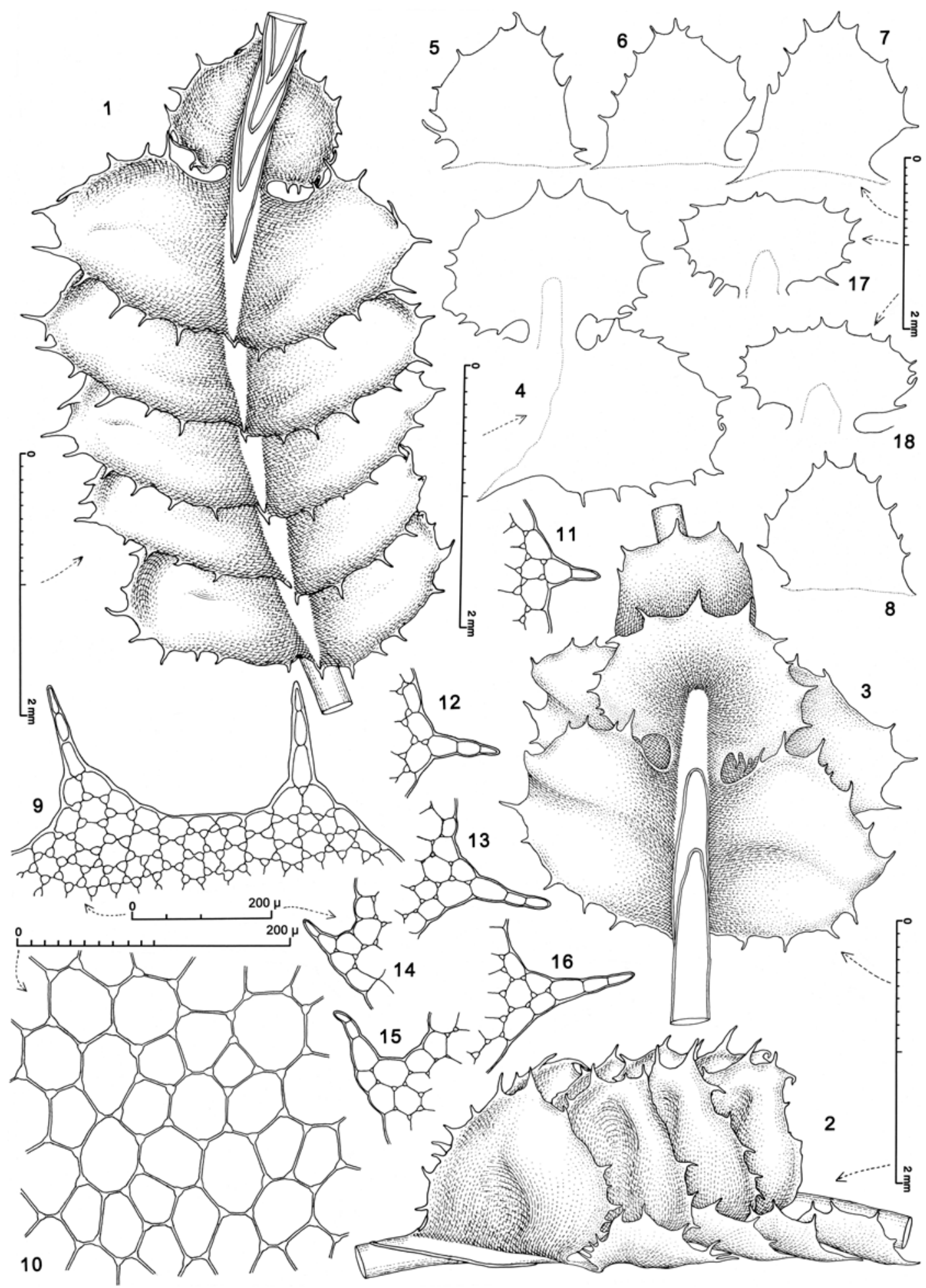


wide elliptic, often slightly to strongly crescentic, at times globose, each with a strong concavity or depression lending a somewhat collapsed appearance, (6.5-)7.2-9.8(-11) $\mu \mathrm{m} \times 4.6-6.5 \mu \mathrm{m}$. Underleaves broad, to $6.5 \times$ the stem width, distinctly and symmetrically united to the leaves on both sides, the connate portion 2-4(7) cells wide, the body of the underleaf positioned well above the attached pair of leaves, the insertion strongly arched, inverted 'U'-shaped, the apex of insertion reaching nearly or quite even with the ventral edge of the leaf pair next above; underleaves erect-appressed, imbricate, the stem not or barely exposed just below the ' $U$ '-shaped insertion at each underleaf base, the underleaves large, slightly to distinctly convex (ventral view), transversely broadly orbicular (esp. appearing so in situ) to reniform, the underleaf width $3.0-3.5 \times$ the disc height (from insertion to underleaf apex), the margins and apex plane or somewhat weakly inflexed; apex broadly rounded to less often subtruncate, with 2, closely approximated tooth-like segments separated by a shallow rounded sinus, the segments similar in size to marginal armature or at times smaller; lamina margins rather regularly spinulose toothed, the teeth slender, with a uniseriate row of 2-4 cells, the margin between the teeth \pm straight, the underleaf margins contracted at base, the leaf to underleaf connation with an elongate to occasionally \pm semicircular sinus. Asexual reproduction absent.

Plants dioecious. Androecia minute for plant size, totally hidden by leaves and underleaves and not extending beyond them, short spicate, on highly abbreviated, determinate, lateral-intercalary branches originating immediately dorsal to the leaf-underleaf connation; bracts in 2 pairs, strongly erect, not dorsally assurgent, loosely appressed to bract immediately above, the saccate portion weakly united at the dorsal base with opposing bract; bracts strongly ventricose, the dorsal pocket scarcely defined, the apices not reflexed, weakly toothed with several sharp teeth, the ventral margin crenate, often with a single few-celled tooth and several slime papillae; lobule margin inflexed, with an apical tooth and (below) several blunt teeth and sessile slime papillae; antheridia 1 per bract, the stalk biseriate throughout or 4-seriate at apex; bracteoles free, broadly ovate to subquadrate, the apex shallowly to deeply 2-3-lobed, the bracteoles without antheridia. Mature gynoecia not seen.

Distribution AND ECOLOGY. Endemic to New Zealand. A plant of the penalpine and alpine zones, exceptionally lower. It occurs terricolous in well drained niches such as steep slopes, at times among tussock or under tussock cover or among boulders, often in large, pure patches. For example, on the slopes below Mt. Burns (E of Borland Saddle, Fiordland Natl. Park, 1225-1320 m) plants formed tight masses on a steep slope among tussock in the alpine zone. Also forming pure tufts at side of rill in a mosaic of tussock grass and alpine vegetation along with tarns, rills rocky outcrops and boulderfields (Rainbow Skifield, St. Arnaud Range, E of S end of Lake Rotoiti, 360-1480 m, Nelson Prov.). Less frequently on soil over rock. For example, on Thousand Acres Plateau (Matiri Range, Kahurangi Natl. Park, ca 1100-1200 m, Western Nelson) plants occurred on thick soil over rock on the slope of a sink hole on a mesalike plateau of gentle topography with numerous sink- and erosion-holes with a mosaic vegetation of scrub, tussockland, grassland and herbfields, including Dracophyllum filifolium, Chionochloa pallens, Oreobolus, and Donatia.

COMMENTS. This species is characterized by the soft and spongy texture, and symmetrically broadly ovate to ovate-orbicular leaves, which are \pm evenly toothed all around (Fig. 1: 1, 4-8). The initial aspect is that of a H. ammophilus (Colenso) R. M. Schust. with teeth, and the specific epithet is intended to call attention to that illusion. The plants are characteristically rather turgid in appearance, somewhat resembling $H$. menziesii in dorsal aspect, with strongly dorsally assurgent, undulate, suborbicular leaves, with the ventral half concave and the dorsal half convex, the leaf apices inflexed and almost touching (Fig. 1: 2). Heteroscyphus menziesii may be immediately distinguished by having underleaves bifid to up to half their length.

When the leaves are widely, almost horizontally spreading (or when the leaves are spread apart with forceps) the distinctly broadly arched, toothed, al- 
most plane dorsal leaf margins, oriented at right angles to the stem (Fig. 1: 1), H. dentammophilus is easily differentiated from $H$. billardierei (Schwaegr.) Schiffn. Heteroscyphus billardierei also has prominently toothed dorsal margins, but this species may be distinguished from the above and other phases of H. dentammophilus by the asymmetrically deltoid leaves, with the dorsal margin narrowly reflexed, quite straight and obliquely oriented toward the shoot apex. When optimally developed, H. dentammophyllus has marginal dentition that gives the plants a 'prickly' appearance, with both margins bearing short, sharp teeth similar in size and shape to those of the apex.

The underleaves are rather strongly contracted at the base (Fig. 1: 3, 4), and thus in situ appear suborbicular in outline; the sinus at the union of leaf and underleaf is rather narrowly elongate (Fig. 1,3,4) and usually not semi-circular and reflexed as in $\mathrm{H}$. billardierei. The leaf-underleaf connation is typically rather narrow, and varies from 2-4(7) cells wide.

SELECTED SPECIMENS SEEN: NEW ZEALAND. South ISLAND. Southland PROV.: Fiordland Natl. Park, plateau and slopes below Mt. Burns, E of Borland Saddle, S of South Branch of Borland Burn, W of Monowai, 1225-1320 m, Engel 18584 (F); Fiordland Natl. Park, Gertrude Valley, near track entrance to Gertrude Saddle, E of Homer Tunnel, 1740 m, Engel 21963 (F). Westland/Canterbury Prov. Boundary: Arthur's Pass Natl. Park, Otira Valley Track, along Otira River, NE of Mt. Rolleston, 1210-1310 m, Engel \& von Konrat 22897 (F). WeSTERN NELSON: Kahurangi Natl. Park, Matiri Range, Thousand Acres Plateau, ca 1100 1200 m, Engel \& von Konrat 27051 (F); Kahurangi Natl. Park, Garibaldi Ridge, vicinity of Gordon's Pyramid, 1335 m, Engel \& von Konrat 27105 (F).

\section{Heteroscyphus menziesii (Mitt.) J. J. Engel, comb. nov.}

Chiloscyphus menziesii Mitt. in Hooker f., Bot. Antarc. Voy. 2: 139. pl. 98, f. 1. 1854. TYPE: New Zealand, Menzies; New Zealand, Port Preservation, Lyall.

\section{Heteroscyphus parallelifolius J. J. Engel, sp. nov.}

Caules mediocres, usque ad $3.8 \mathrm{~mm}$ latae. Rami exacte laterali-intercalares. Insertio folii dorsaliter ad lineam medianam non attingens. Folia contigua vel laxe im- bricata, ambitu anguste oblonga vel lineari-lanceolata, marginibus integris praedita, distincte bifida per lobos subcaudatos qui in seriem uniseriatam ex usque $8 \mathrm{cel}$ lulis terminantes. Amphigastria utrinque connata, profunde bifida, lobis caudatis, divergentibus vel interdum subparallelis, marginibus ambarum loborum laminarumque amphigastrinis plerumque omnino integris.

Holotype: NEW ZEALAND, NORTH Is., NORTH AuCKLAND PROV., NE Waitakere Ranges, Swanson University Reserve, Tram Valley Road, 95 m, Engel 20433 - c. $\widehat{\jmath}$ (F); ISOTYPE: (AK).

=Lophocolea helmsiana var. subparallela E. A. Hodgs., Trans. Roy. Soc. New Zealand 80: 352. pl. 77, f. 35. 1953, syn. nov. TYPE: New Zealand, Thames, Kirk 454, Bot. Div. Herb. no. 6017 (CHR!).

Plants soft and flexuous, loosely prostrate to stiffly ascending, at times loosely pendent, pale green, somewhat translucent, nitid both live and when dry, the shoots medium sized, to $3.8 \mathrm{~mm}$ wide. Branching rather common, at times copious, the branches strictly of lateral-intercalary type. Stems narrow for plant size, the cortex weakly differentiated, in 1 layer of slightly firm-walled cells that dorsally are \pm similar in size to the medullary cells and ventrally moderately smaller; medullary cells firm walled. Rhizoids in tight fascicles from stem at immediate base of underleaves. Leaves subopposite, horizontal, widely spreading to squarrose, contiguous to weakly imbricate, occasionally subfalcate, free dorsally, the orientation and insertion strongly succubous, almost longitudinal, forming a \pm straight line for its entire length, the lines of insertion rather distant from stem midline dorsally and delimiting a broad leaf-free strip of 5-6 cells wide; leaves slightly convex, somewhat more strongly so in dorsal third of leaf, \pm canaliculate distally in dried plants, narrowly oblong to linear-lanceolate, the subfalcate leaves occasionally very narrowly ovate, the leaves often contracted slightly below the 'fork', bifid to $0.20-0.25$; lobes \pm parallel to moderately diverging, subequal or the ventral somewhat larger, the lobes subcaudate, terminating in a uniseriate row of 6-7(8) moderately elongated cells contricted at the septa, the lobe margins entire; sinus rounded, occasionally feebly angular; lamina margins entire, the dorsal straight or nearly so, moderately deflexed (often rather 
sharply so), long decurrent at the base, the ventral \pm straight or slightly and broadly curved. Leaf cells with walls thin, occasionally with knot-like to lens-like intermediate thickenings on vertical walls, trigones distinct, small to medium, the median leaf cells $23-30 \mu \mathrm{m}$ wide $\times 37-47 \mu \mathrm{m}$ long, the median basal cells somewhat larger; marginal cells not differentiated, a border lacking; surface smooth. Oil-bodies hyaline, 3-6 per cell, finely botryoidal in some leaves, coarsely botryoidal in other leaves of same population, elliptic to fusiform, a few weakly crescentic, occasionally spherical, $10.8 \times 6.9 \mu \mathrm{m}$ to $17.6 \times 5.9-6.9 \mu \mathrm{m}$. Underleaves to $2.3 \times$ stem width (measured at maximum width of lamina), distinctly and somewhat asymmetrically united to the leaves on both sides (the connation a little lower and narrower on 1 side), the insertion often asymmetric, the connate portion 3-4(5) cells wide, the body of the underleaf positioned above the attached pair of leaves, the insertion shallowly inverted U-shaped, the apex of insertion extending to the ventral extremity of the associated leaves (with which the underleaf is connate) or a little beyond (extending to the midpoint or somewhat below of the leaf pair next above); underleaves moderately to strongly spreading, the lobes often recurved, the underleaf lamina distant from one another but the lobe tips extending to the level of the sinus or beyond of the underleaf above, the stem broadly exposed, the underleaves slightly concave (ventral view), long cuneate to long rectangular, deeply bifid by a moderately rounded to lunate sinus, the lamina 3-5(6) cells high from insertion to sinus base; lobes broadly diverging to (chiefly in suboptimal populations) \pm parallel, caudate, typically biseriate for 2-5 tiers of cells and ending in a uniseriate row of 8-13 cells similar to those of the leaves, the lobe margins uniformly entire; lamina margins often slightly reflexed, entire, rarely or sporadically with a ciliiform process on 1 side; leaf to underleaf connation reflexed, entire. Asexual reproduction absent.

Plants dioecious. Androecia totally hidden by leaves and not extending beyond them, subspicate, on abbreviated, determinate, lateral-intercalary branches, the androecia with 2-4 pairs of bracts; bracts erect, dorsally assurgent, loosely appressed to bract immediately above, the saccate portion fused with opposing bract; bracts strongly ventricose-cucullate, the dorsal pocket rather ill-defined, the bracts distinctly bifid, the lobes acuminate, terminating in a uniseriate row of $2-3$ cells, the ventral margin often with $1-2$ teeth in distal portion, the dorsal margin often with a prominant tooth just distal to the lobule; lobule margin dilated, involute, crenate-denticulate by several 1 to few-celled teeth; antheridia one per bract, the stalk biseriate; bracteoles distinctly connate on 1 side, free or feebly connate on the other, narrowly long rectangular, deeply bifid, without antheridia. Gynoecia seen only in juvenile state, on short intercalary branches.

Distribution AND ECOlOGY. Endemic to North Island, New Zealand, and occurring in Auckland Ecological Province, from the Kaimai Range northward to Kiwanis Reserve at the northern edge of the Herekino Forest area.

A plant of humid sites within forests, usually growing loosely prostrate, often on vertical clayey shaded banks above streams. For example, in Waipoua Forest (Waikohatu Stream, 290 m, North Auckland Prov.) plants occurred on a vertical bank of a stream and formed a very loose pendent sheet that became epiphyllous on hymenophylls in a kauri (Agathis) forest with Weimannia silvicola in a steep-sided stream valley. Also, at Kiwanis Reserve ( $\mathrm{N}$ edge of Herekino Forest area, $c a 5 \mathrm{~km} \mathrm{~S}$ of Kaitaia, $c a$ 60-80 m, North Auckland Prov.) present on a hanging lip of the upper extent of a stream bank at the forest edge in a mixed broadleaf forest

Fig. 2. Heteroscyphus parallelifolius J. J. Engel. 1 - Shoot, ventral view; note undivided leaf (arrow a) and leaves with a tooth on ventral margin (2 arrows, b). 2 - Sector of shoot, dorsal view. 3 - Leaves. 4 - Leaf apex. 5 - Distal portion of leaf lobe (note intermediate thickenings on some vertical walls). 6 - Portion of leaf lobe. $7 \& 8$ - Underleaves. 9 - Underleaves. (Figs. 1-5, 7, 9, from Engel 20888, New Zealand, North Is., North Auckland Prov., Kiwanis Reserve; 6 \& 8, from Engel 20987, New Zealand, North Is., North Auckland Prov., Omahuta Forest Kauri Sanctuary Prov.). 


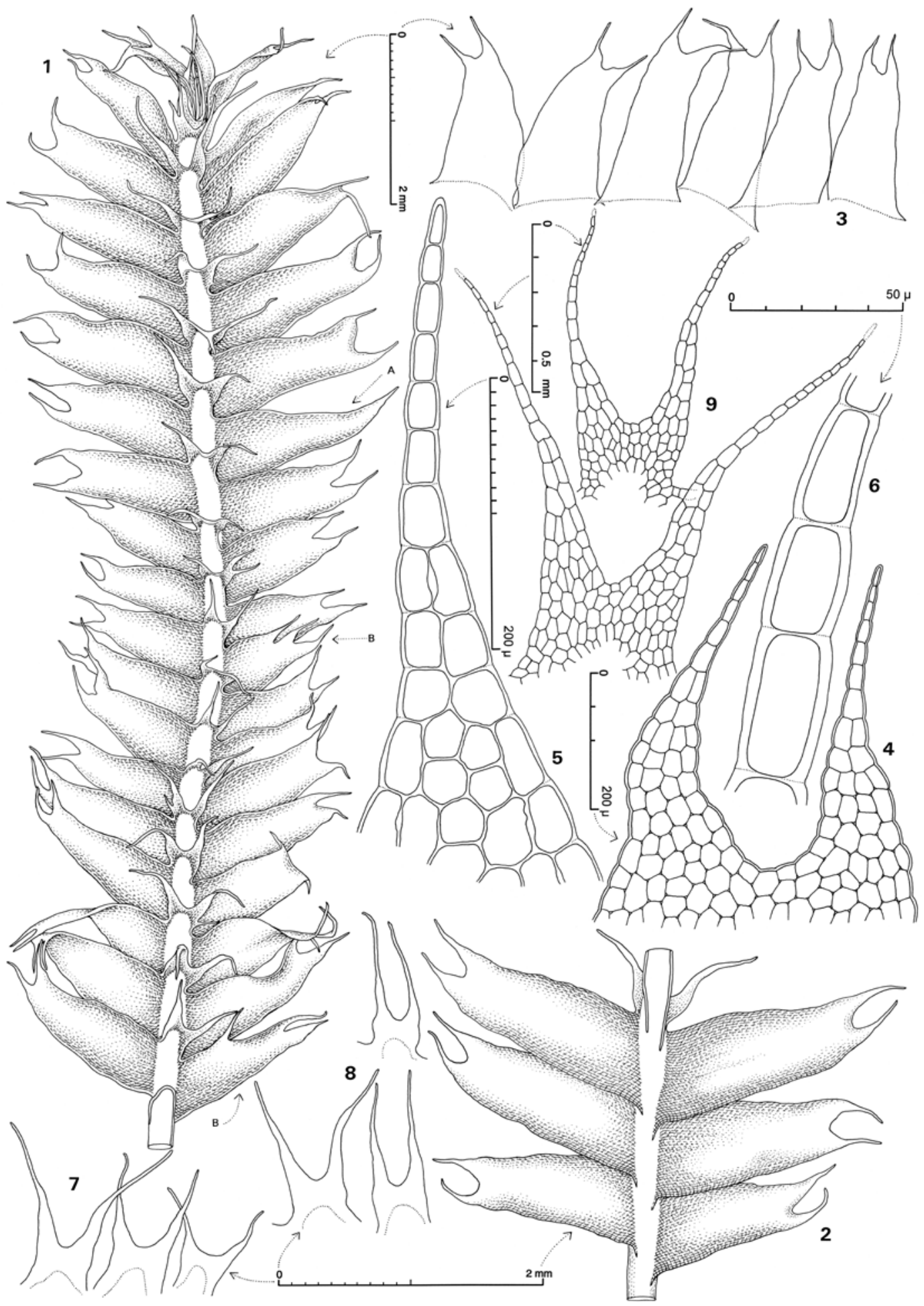


dominated by Beilschmiedia and Vitex, with nikau palm (Rhopalostylis), Coprosma, Dacrycarpus and Hoheria. Less often on Cyathea or over rock.

COMMENTS. This rather stenotypic species has a distinctive appearance. The leaves are contiguous to at most loosely imbricate (Fig. 2: 1), with a marked leaf-free gutter of 5-6 dorsal stem cells (Fig. 3: 3). Leaf form is unusual for AustralAsian Heteroscyphus species: narrowly oblong to linearlanceolate (often contracted slightly below the 'fork'), entire margined and distinctly bifid by subcaudate lobes that terminate in a uniseriate row of up to 8 cells that are constricted at the septa (Fig. 2: 4-6). While the typical leaf form for the species is bifid and entire-margined, some populations have sporadic leaves that are undivided, narrowly ovate and gradually taper to the summit (Fig. 2: 1, arrow a) and, rarely, others with a strong tooth on the ventral margin (Fig. 2: 1 , arrow b). The distinctive underleaves are connate on both sides, deeply bifid by lobes that are caudate and diverging to, occasionally, \pm parallel (Fig. 2: 1, 7-9); both lobe and lamina margins typically are completely entire. Underleaves rarely or sporadically have a ciliiform process on 1 side (Fig. 2: 1). Less well-developed plants have underleaves with lobes mostly parallel, but they remain caudate. Underleaf lobes gradually taper and typically consist of at least 2 biseriate tiers of cells before narrowing to the long and whip-like uniseriate portion (Fig. 2: 9). Leaf cell walls are thin, with intervening trigones distinct and medium in size. Noteworthy knot-like to lens-like intermediate thickenings are typically present on scattered vertical walls (Fig. 2: 5; 3: 6). Oil-bodies are unusual for the genus in being botryoidal (Fig. 3: 4).

Possible confusion may occur with $H$. colensoi (Mitt.) Schiffn., which also has a leaf-free strip of stem cells, oblong, bilobed and entire-margined leaves and underleaves that are deeply bifid and connate on both sides. Heteroscyphus colensoi, however, may be distinguished by leaf apex teeth or lobes much smaller, with an intervening truncate sinus, and by the typically dentate margins of the underleaf lamina.

\section{Heteroscyphus stoloniferus J. J. Engel, sp. nov.}

Heteroscypho fursistipulo (E. A. Hodgs.) J. J. Engel \& R. M. Schust. similis, sed plantis strictis, rigide flexuosis, quoad staturam minore (caulibus usque $1.1 \mu \mathrm{m}$ latis), stolonibus praesentibus, ambitu foliorum ovatis vel ovato-subquadratis vel breve ovato-ellipticis vel lingulatis, marginibus laminalibus amphigastrinis plerumque integris differt.

Holotype: NEW ZEALAND, South Is., Sounds Nelson Ecological Province, Aniseed Valley, Hackett (Whispering) Falls Walk, SE of Richmond Township via Aniseed Valley Road off State Highway 6, 220270 m, Engel and von Konrat 27008 - c. $\delta$ (F); ISOTYPE: (CHR).

Plants stiff and wiry, ascending to (with crowding) suberect, golden brown to light brown on Chatham Is., pale, translucent and whitish green toward shoot apices, the shoots rather small, to $1.1 \mathrm{~mm}$ wide. Branching rather common, the branches of lateral-intercalary type, from lateral half of underleaf axil grading to immediately dorsal to the leaf-underleaf connation, the branches also from ventral-lateral side of stem some distance apical to the underleaf axil (and just basal to the underleaf above), the branches often denser leaved and considerably narrower than main shoot in diam.; ventral-intercalary branches also present, from middle of underleaf axil; Frullania-type branches lacking; stolons present, ventral intercalary, variable in position on shoot: from median or at times distal third of shoot, less often from near shoot base, pale, almost whitish, bristly in appearance due to the stiffly spreading rhizoids and scale-like leaves, the leaves 2(3)-lobed nearly to base. Stems only 7-8 cells high, the cortex somewhat differentiated, in 1 layer of somewhat smaller, moderately thick walled, pigmented cells; medullary cells thin walled. Rhizoids not seen. Leaves alternate, stiffly dorsally assurgent, the adaxial faces of opposing leaves often facing one another, the leaves typically obliquely (not widely) spreading, loosely imbricate, free dorsally, the orientation and insertion strongly succubous, not decurved at ventral end, the lines of insertion not extending to stem midline dorsally and delimiting a broad leaf-free strip 


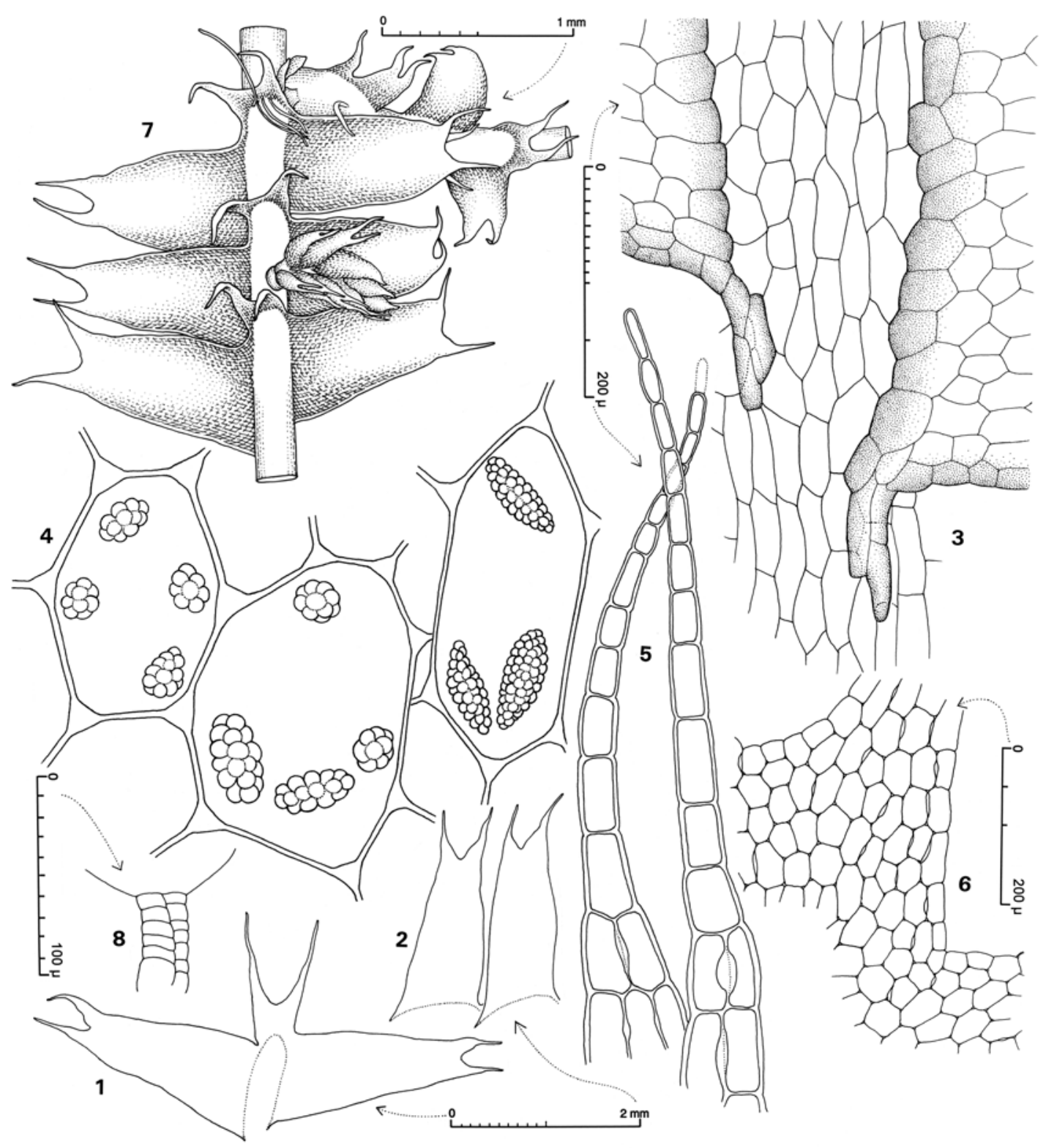

Fig. 3. Heteroscyphus parallelifolius J. J. Engel. 1 - Two leaves and an underleaf. 2 - Leaves. 3 - Dorsal surface of stem showing leaf insertion lines and leaf-free strip (the leaf cells shaded). 4 - Median leaf cells with oil-bodies $(\times 805) .5$ - Underleaf lobes. 6 - Lateral half of underleaf showing only lobe base (arrow indicates deepest point of sinus) + leaf-underleaf connation. 7 - Sector of shoot with androecium $(=\pi)$ and lateral-intercalary branch $(=1 \mathrm{ib})$, ventral view. 8 - Antheridial stalk. (Figs. 1 , 3, 5, 6, from Engel 20888, North Is., North Auckland Prov., Kiwanis Reserve; 2 \& 4, from Engel 20987, New Zealand, North Is., North Auckland Prov., Omahuta Forest Kauri Sanctuary Prov.; 7 \& 8, from Engel 20433, New Zealand, North Is., North Auckland Prov., NE Waitakere Ranges, Swanson University Reserve). 
of 2-3 cells wide; leaves concave to, occasionally, slightly convex, typically subsymmetrically ovate to ovate-subquadrate to short ovate-elliptic, on particularly vigorous shoots oblate, in some populations often lingulate to ovate-elliptic; apex undivided and broadly rounded to truncate to weakly emarginate, the apices and margins uniformly entire; dorsal margin broadly and gently curved, plane to moderately inflexed, the base short decurrent; ventral margin broadly curved, the curvature \pm like the dorsal margin, plane to moderately inflexed. Leaf cells with walls thin, trigones large and slightly to distinctly bulging, the median leaf cells $24-32 \mu \mathrm{m}$ wide $\times 26-35 \mu \mathrm{m}$ long; surface smooth. Oil-bodies occupying moderate portion of cell lumen, dull greyish, 2-3 per median leaf cell, coarsely papillose/finely botryoidal. Underleaves $1.5-2 \times$ stem width, connate on 1 side by a strip $2-4$ cells wide, and free or more narrowly connate on the other side, the orientation and often the insertion somewhat asymmetric, inverted U-shaped but not strongly so; underleaves weakly to moderately spreading, approximate, plane to weakly convex (ventral view) at least in distal sector of lamina, oblong-subrectangular to short ovate (particularly vigorous shoots), in some populations frequently narrowly cuneate, bifid to $0.5-0.7$; lobes typically \pm parallel, plane, acuminate to (often) lanceolateattenuate, often apiculate, terminating in a single cell, or, more often, a uniseriate row of 2-4 cells that are at most slightly longer than wide, the lobe margins entire; lamina margins typically entire, at times with a laciniiform process on 1 of margins or, exceptionally, on both margins, the lamina margins otherwise entire. Asexual reproduction absent.

Plants dioecious. Androecia small but rather conspicuous since they spread at an oblique angle from the underleaf axil and the leaves above them are stiffly dorsally assurgent, the androecia vermiform, on short, abbreviated, typically determinate, ventral-intercalary branches (from middle of un- derleaf axil), the branches also lateral intercalary (from lateral half of underleaf axil), the androecial branches sporadically proliferating vegetatively distally (the androecium then basal on a branch), the ensuing branch may, in turn, eventually produce an androecium; bracts in 3-8 pairs, strongly erect, moderately dorsally assurgent, loosely imbricate to closely appressed to bract immediately above, the saccate portion fused toward base with opposing bract; bracts strongly ventricose, a basal, more swollen portion not or a little defined, the apices plane or weakly inflexed, 3-4 often asymmetrically lobed to $c a 0.35$, the lobes often incurved and clawlike, the dorsal lobe largest, the middle lobe about the same size or smaller, the ventral lobe similar or, often, reduced to a small projection capped by a slime papilla, the lobes terminating in 2 laterally juxtaposed cells or a single cell or a uniseriate row of 2 subisodimetric cells, the ventral margin of bract entire; lobule ill-defined, the dorsal margin incurved and a little dilated, with a well-defined tooth distally; antheridia 1 per bract, only old antheridia seen; bracteoles \pm narrowly subrectangular, bifid to $c a 0.5$, the lobes with a pair of laterally juxtaposed cells at base, then with a single cell or a uniseriate row of 2 cells, the disc comprised of 2 tiers each 4 cells wide, the bracteoles without antheridia. Gynoecia seen only in very young state, on abbreviated ventral-intercalary branches lacking normal, vegetative leaves.

COMMENTS. Heteroscyphus stoloniferus closely resembles $H$. furcistipulus (E. A. Hodgs.) J. J. Engel \& R. M. Schust. but bears stolons (Fig.4: 1) and is a smaller plant (the shoots to $1.1 \mathrm{~mm}$ wide), golden brown to light brown in color and with a different texture, being stiff and wiry, whereas $H$. furcistipulus lacks stolons and is larger, olive green, and with a notably soft and spongy texture. The leaves of $H$. stoloniferus are obliquely spreading (except in some populations with lingulate leaves) and

Fig. 4. Heteroscyphus stoloniferus J. J. Engel. 1 - Portion of shoot with stolon (in distal sector of shoot), lateral view. 2 \& 3 Portion of shoot (ventral view); note asymmetry of orientation and insertion of underleaves. 4-13 - Leaves. 14 - Median leaf cells. 15 - Oil-bodies of median leaf cells. 16 \& 17 - Underleaves. 18 - Bract. (Figs 1, 2, 4-6, 14-18, from type; 3, 10-13, from de Lange 2215, Chatham Islands, (Pitt Island), Waipaua Bay, Waipaua, Waipaua Stream Outlet (F); 7-9, from Engel 27009, same loc. as type). 


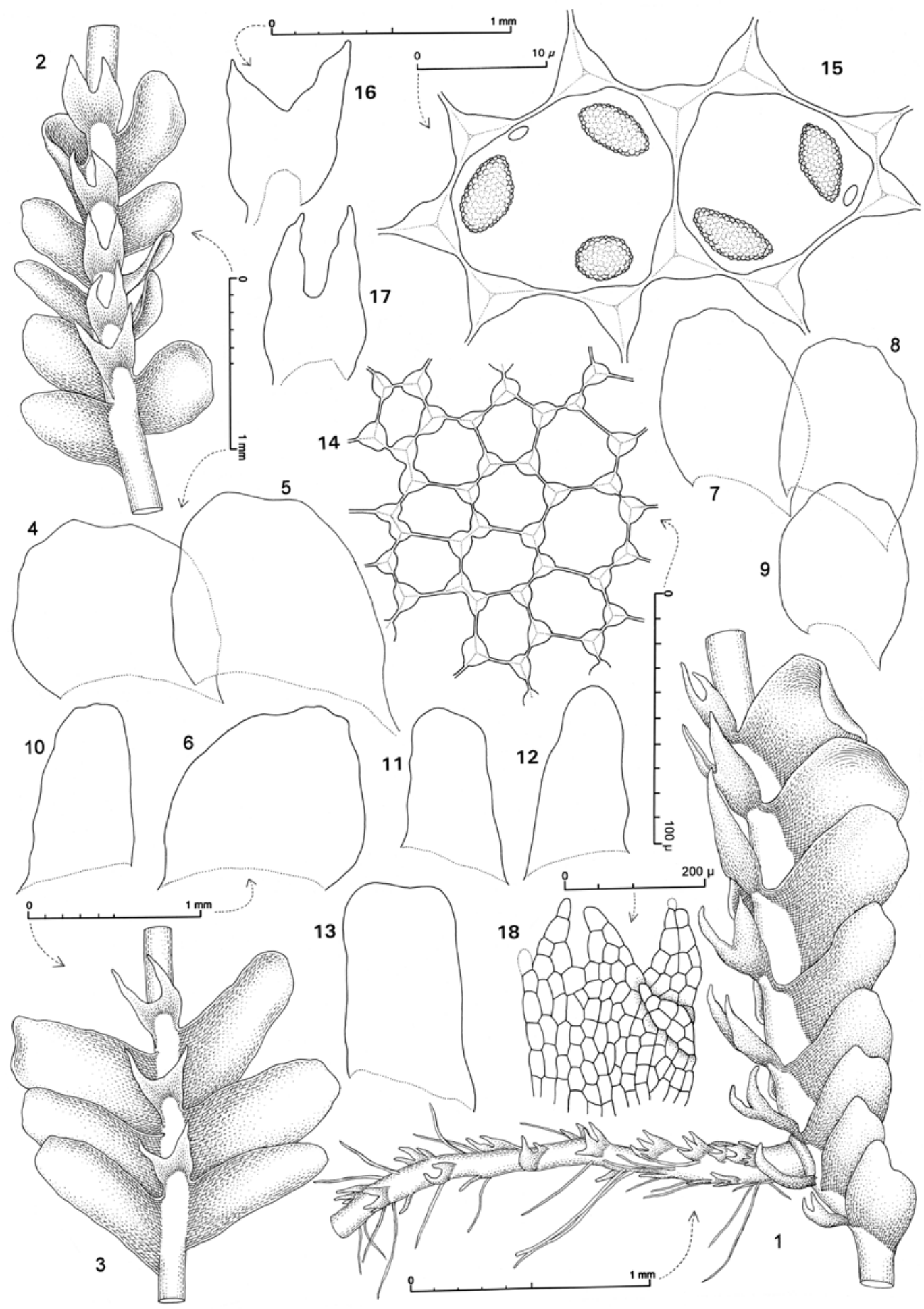


ovate to ovate-subquadrate to short ovate-elliptic to lingulate in shape (Fig. 4: 4-13), and oblate only on particularly vigorous shoots vs. widely spreading and oblate to ovate leaves in H. furcistipulus. In $H$. stoloniferus the underleaf lamina margins are typically entire (Fig. 4: 3, 16, 17), and less often have a laciniiform process on one margin and only exceptionally have a laciniiform process on each side, whereas in H. furcistipulus the underleaf lamina margins often have a laciniiform process on each side.

This is the only member of Heteroscyphus or Chiloscyphus that I know of that has stolons (Fig. 4: 1). The stoloniform branches are ventral intercalary and variable in position on the parent shoot, originating from the median or at times the distal third of the shoot (Fig. 4: 1), and less often from near the shoot base. They occur singly per shoot and do not branch; at no time is there formation of a basal system of branched stoloniform axes.

The species has two phases. In one phase the plants have leaves obliquely spreading and typically ovate to ovate-subquadrate to short ovate-elliptic (Fig. 4: 4-9) and underleaves oblong-subrectangular to short ovate. Plants of the other phase have leaves that are widely spreading, often lingulate to ovate-elliptic (Fig. 4: 10-13), only sporadically ovate-subquadrate and underleaves mostly narrowly cuneate and less often narrowly oblongsubrectangular. I suspect that plants of the latter phase are somewhat suboptimal, but this should be tested with study of larger suites of specimens.

DistriBUTION AND ECOLOGY. Known only from a few low-elevation collections. Type plants occurred at 220-270 m over soil of a bryophyte covered, exposed, steep, calcareous bank above Hackett Stream in Sounds Nelson Ecological Province. Known also from the Fox River Valley (Nelson, $15 \mathrm{~m}$ ) at a second calcareous site: on the side of a gorge of the Fox River plants formed a thick, large cushion on a boulder face in a boulder field of limestone rocks with a subterranean stream surfacing near and entering into the Fox River in the vicinity of a cave.
The species is disjunct on Rangiauria (Pitt Island), Chatham Islands. At Waipaua Bay plants are confined to overhangs under dense coastal vegetatian in deep shade and are associated with seepages in coastal cliffs above the beach. Admixed are Nostoc sp. and the moss Tetracoscinodon irroratus (Mitt.) R. H. Zander. The site is made up of base-rich ironsands and basaltic tuff. Peter de Lange (AK, in litt.) commented that the moss, according to Allan Fife (CHR), normally is associated with limestone; de Lange has seen the moss on a variety of base-rich substrates.

SPECIMENS SEEN: NEW ZEALAND. SOUTH ISLAND. NELSON PROV.: Paparoa Range, N side of gorge of Fox River in vicinity of cave, NE of Punakaiki, $15 \mathrm{~m}$, Engel 19105 (F). CHATHAM ISLANDS: Rangiauria (Pitt Island), Waipaua Bay, Waipaua, Waipaua Stream Outlet, ca 3 m, de Lange CH2215 (AK, F).

ACKNOWLEDGEMENTS. I gratefully acknowledge support of the National Science Foundation (Grants BMS76-03616 and DEB-8109680), which funded field work in New Zealand, Tasmania and Australia. I am grateful to the National Geographic Society, which supported field studies in New Zealand (Grants 5375-94, 5795-96, 7379-02, 7927-05, and 8132-06). I also wish to thank Zorica Dabich for preparing the habitus figures of the illustrations, David Sollenberger for preparing the oil-body illustrations and for assistance with several of the illustrations, Patricia Eckel for the Latin diagnoses and for valuable advice, Laura Briscoe for her assistance, and Kevin Havener for his excellent work with electronic files of the illustrations. Many thanks to Peter de Lange for his interest and support as well as for valuable advice. I acknowledge with thanks the contributions of Gary Merrill. Special thanks to Matt von Konrat for valuable assistance in the field and in the laboratory at Field Museum. I acknowledge, with thanks the Nagaunne Fund, Field Museum.

\section{REFERENCES}

Engel J. J. \& Schuster R. M. ['1984’] 1985. An overview and evaluation of the genera of Geocalycaceae Subfamily Lophocoleoideae (Hepaticae). Nova Hedwigia 39: 385-463.

MARTIN W. 1950. The bryophytes of Stewart Island. Part II. Trans. \& Proc. Roy. Soc. New Zealand 78: 485-501. 